\title{
Implementation of Web-Enhanced Course-Based Virtual Reality for Entrepreneurship Learning to Create Islamic Social Entrepreneur in The New Normal
}

\author{
Heny Kusdiyanti ${ }^{1}$, Mokhammad Nurruddin Zanky¹, Indra Febrianto², and \\ Robby Wijaya ${ }^{2}$ \\ 1'Department of Management, Faculty of Economics, Universitas Negeri Malang \\ ${ }^{2}$ Postgraduate Faculty, Universitas Negeri Malang
}

ORCID:

Heny Kusdiyanti: http://orcid.org/0000-0001-6637-8100

\section{Abstract}

The aim of this research was to develop interactive learning media by using webenhanced and virtual reality technology, in order to promote young entrepreneurship

Corresponding Author: Heny Kusdiyanti

heny.kusdiyanti.fe.ac.id

Published: 14 July 2021

Publishing services provided by Knowledge E

(c) Heny Kusdiyanti et al. This article is distributed under the terms of the Creative Commons Attribution License, which permits unrestricted use and redistribution provided that the original author and source are credited.

Selection and Peer-review under the responsibility of the IRCEB Conference Committee. in this new normal era. A descriptive approach was used and data were collected from teachers and students. The media that was developed can change the economic behavior and lifestyle of high school students through promoting profitable entrepreneurial activities. The results showed that teacher competence was increased. There are several components of the implementation process, such as the delivery of material, interaction with the material, interaction with a teacher, interaction with other students, and intra-action. The results showed that the implementation of the learning media increased teacher and student activity in entrepreneurship learning. The results were shared with other researchers and the government to encourage them to participate and take initiative to implement entrepreneurship learning by using this technology.

Keywords: Disruptive Learning, MSME's, Virtual Reality, Web-Enhanced

\section{Introduction}

MSME's has the huge contribution on the improvement of economic development.. Entrepreneurship is an important thing to be up against intellectually challenging (Ramoglou \& Tsang, 2016). It also supports the discovery scholarship's treatment of opportunity for an entrepreneur as a physically observable object (Ramoglou et al., 2014). On the one hand, financial value improvement can be achieved by academic 
the entrepreneurship in the border area is less paid attention (Kurowska-Pysz, 2016). The policies made can not be felt by an entrepreneur in the border area to increase their business. This problem is the beginning of the community in the border area not interested in entrepreneurship. They did not get access to get knowledge about establishing new enterprises.

Furthermore, the enterprises in the border area have a major contribution to the development of community welfare. Enterprises in the border area must be massively developed to spread their contribution to community welfare (Kurowska-Pysz, 2016). Based on the current condition, social entrepreneurship activity is very important to reduce that social problem in the border area. Social entrepreneurship has been described by several intellectuals with different domains or themes of interest (Short, Moss, \& Lumpkin, 2009). That is why many social entrepreneurs are needed to build a community in the border area. But, these study mostly discuss faith-based organization, entrepreneur and their relations with religiosity. There was no study that discuss about how is social entrepreneur can be empowering social community in border area especially in the islamic context. Therefore, this study try to elaborate the contribution of social entrepreneur by empowering community in border area in the islamic context.

Hence, the belief in Islam in a Moslem country is still very strong. That is why the implementation of this concept is very suitable to be applied in a Moslem country such as Indonesia.

Based on the word of Allah in Surah Al-Baqarah 2;245 which means:

"Who is he that will lend to Allah a goodly loan so that He may multiply it to him many times and it is Allah that decreases or increases (your provision), and unto Him, you shall return."

(Al-Qur'an, n.d.)

And on the one hand, Prophet Muhammad in the Moslem recorded from Abu Hurayrah said,

"Wealth never decreases because of Sadaqah (charity). Allah never increases a servant who gives in charity except in honor, and whoever is humble for the sake of Allah, Allah will raise him in status."(Hurairah, n.d.)

Based on these Qur'an and Hadith, it can be seen that the social entrepreneur must be adjusted to the Islamic content especially for the Moslem country. It is proven by the activity done by the entrepreneur. 
Understanding entrepreneurship education was not done successfully, several researchers who improve in entrepreneurship education (Cosenz \& Noto, 2017) who created an entrepreneurial learning approach based on dynamic start-up business model simulators, where they try to turn a business idea. This research conducted to focus on developing an interactive learning model by using media of virtual reality connected with web-enhanced to increase teacher competence in entrepreneurship education, especially in this new normal

\section{Research Method}

The research and development model used in this study is to modify the research model developed by Thiagarajan called the 4D model and Walter Dick\&Lou Carey. The following steps have been modified by researchers based on the method below:

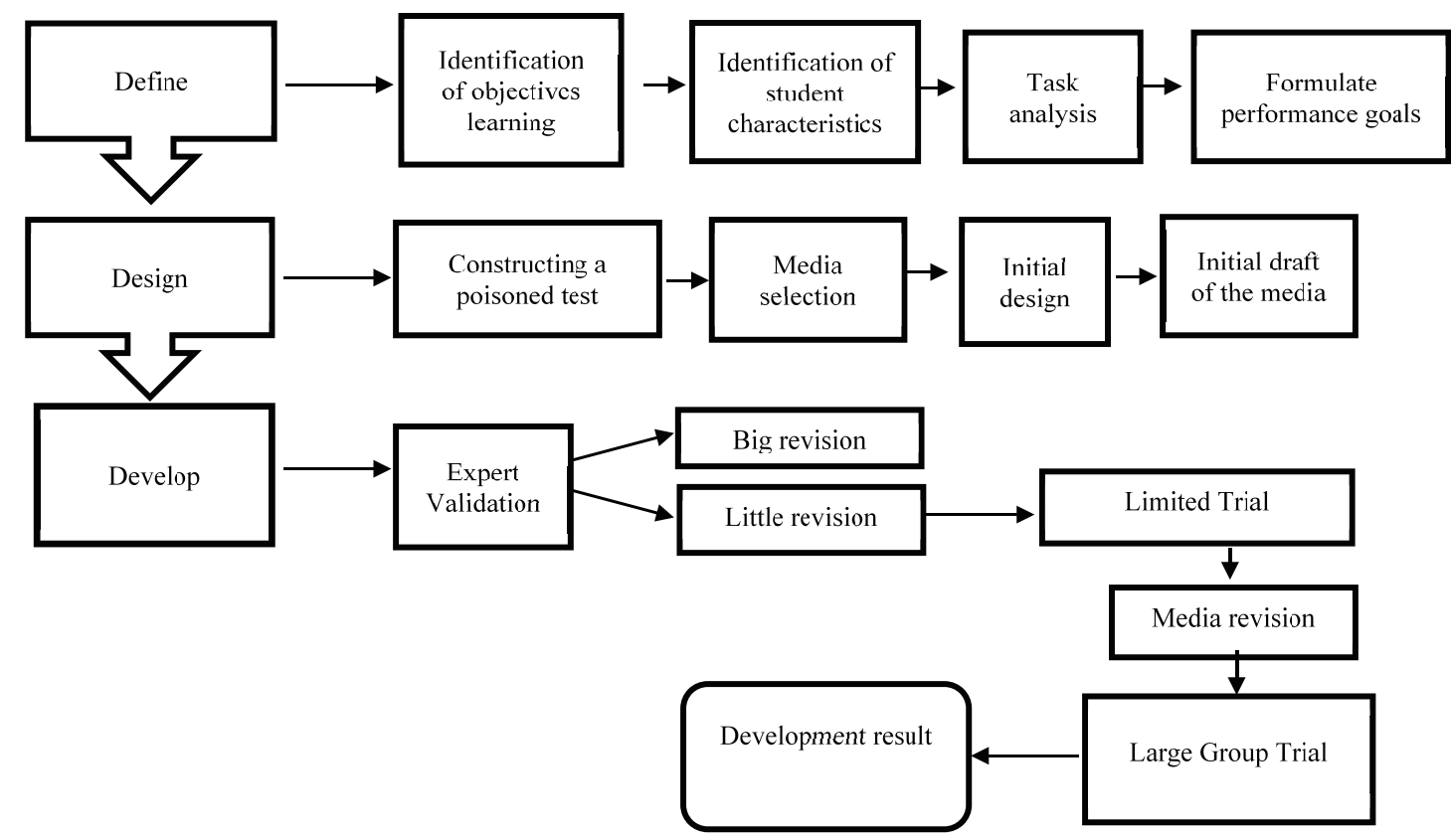

Figure 1: Research and Development Model

This research was preceded by preliminary observations aimed at obtaining data needs in the development of instructional media in the classroom. The testing subjects in the development of this learning media were teachers and students high schools in Malang by virtual. The type of data used is qualitative data obtained through documentation and interviews with validators and respondents, and quantitative data obtained through questionnaires for validators and tests for respondents. 
The data analysis technique used is the percentage descriptive technique. The data obtained is then interpreted with qualitative sentences. The data processing technique used refers to Arikunto's data processing as follows:

$$
P=\frac{x}{x i} \times 100 \%
$$

TABLE 1: Determination of The Percentage of Result

\begin{tabular}{|l|l|}
\hline Percentage & Criteria \\
\hline $80 \%-100 \%$ & Valid to Used \\
$60 \%-79 \%$ & Valid Enough to Used \\
$50 \%-59 \%$ & Less Valid to Used \\
$<50 \%$ & Invalid to Used \\
\hline
\end{tabular}

\section{Result and Discussion}

The first result of this study is the website for entrepreneurship learning media that will be implemented in five high schools located in Malang. The basic principle of this website is the Web-Enhanced Course collaborates with virtual reality that integrates several aspects needed by students in enhancing the capture of entrepreneur learning delivered by the teacher.

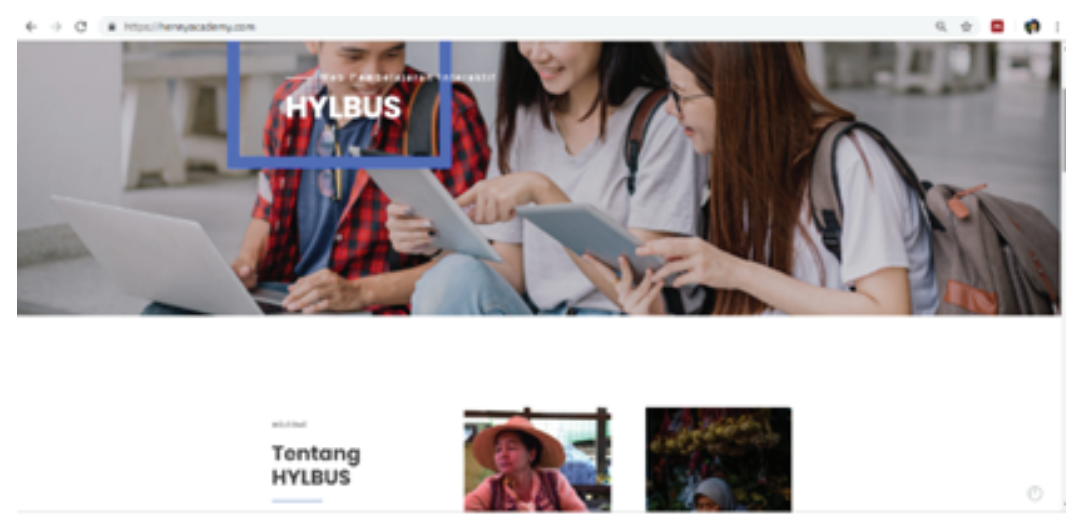

Figure 2: Homepage of Web-Enhanced Course

After has been developed, this website will be collaborated with Islamic social entrepreneurship model to optimize these function. This model will be used by the teacher to get real simulation practice in the entrepreneurship Islamic-based (Boulven et al., 2018). The advantages of the website also can optimize as a learning model in entrepreneurship. This model will encourage students to understand easily about the material and will have good character as an Islamic entrepreneur. This collaboration model can be presented as below: 

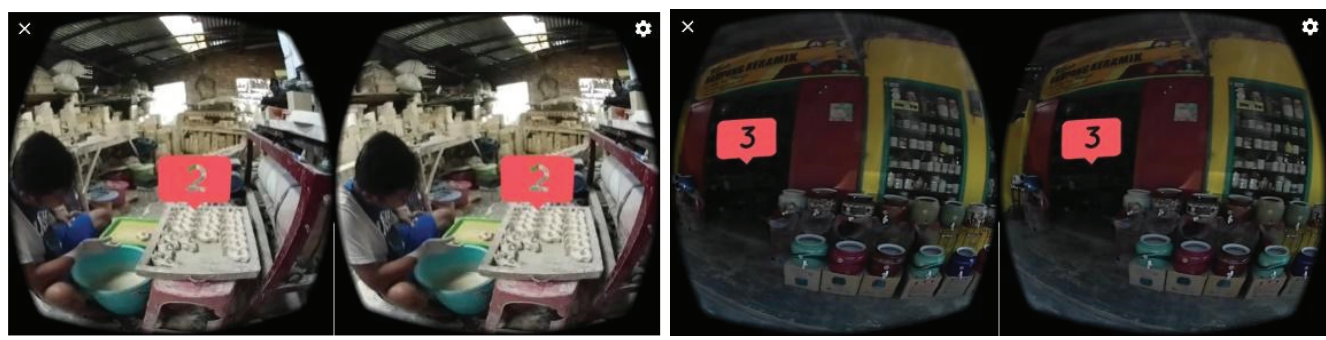

Figure 3: Virtual Reality Visualization

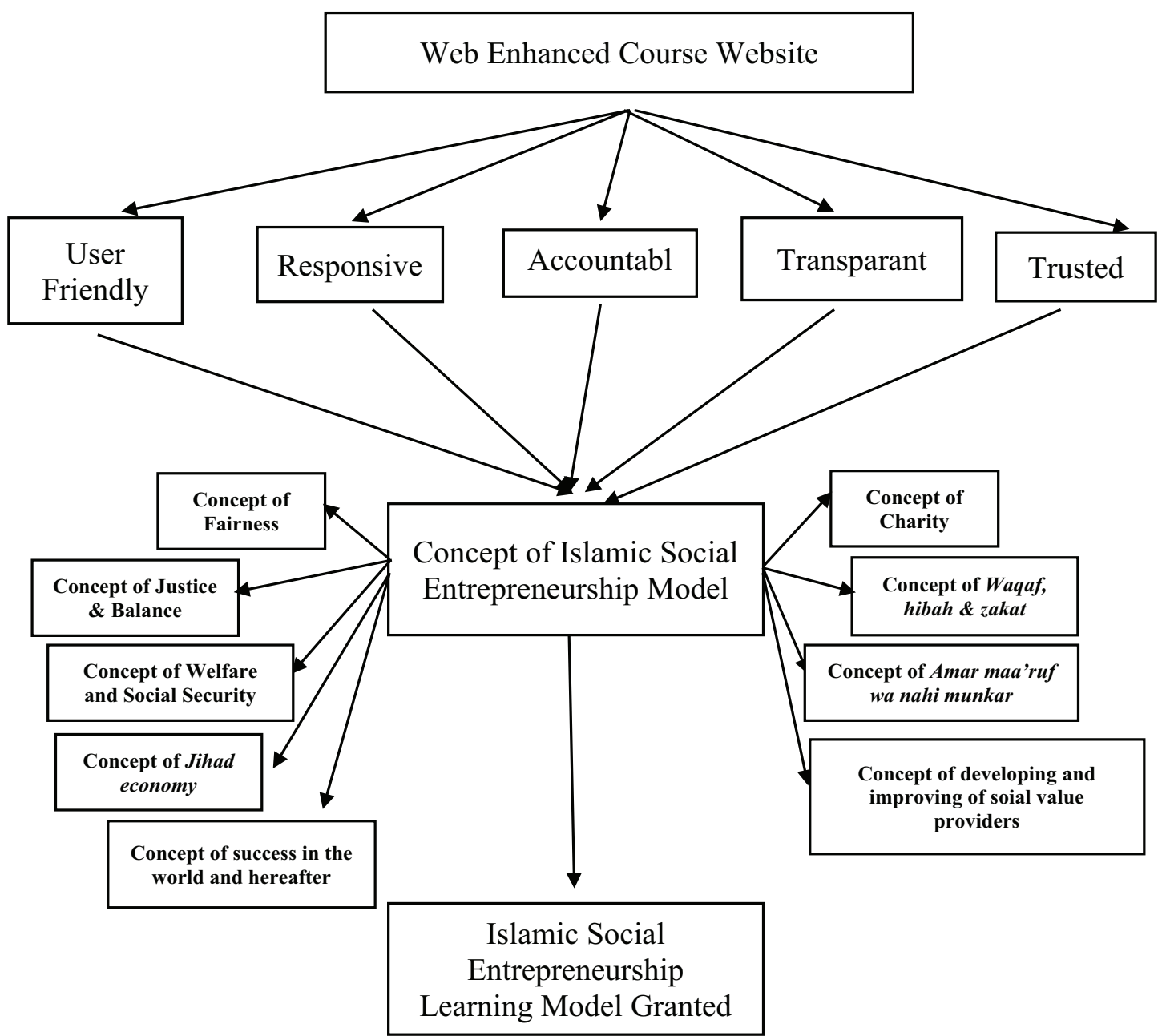

Figure 4: Islamic Social Entrepreneurship Learning Model

The model of the Islamic Social Entrepreneurship Learning Model for high school students is a container that can accommodate the real needs of students in the current situation related to Islamic-based. Also, the most important thing is to give real simulation practice for students in entrepreneur activities. The Islamic content also involves in this learning model because it can be alternatives to eradicate poverty and inequality as a goal of entrepreneurship learning (Ramadani et al., 2016). This targeting of this learning model is 5 hight schools in Malang which have support tools to implement this model. 
This learning model has been proven to increase student and teacher activity in the implementation location such as below:

TABLE 2: Teacher and Student Activity Increasing

\begin{tabular}{|l|c|c|}
\hline Action & Teacher Activity & Student Activity \\
\hline Pre-Action & $65,27 \%$ & $50,63 \%$ \\
\hline Action 1 & $84,72 \%$ & $83,97 \%$ \\
\hline Action 2 & $88,48 \%$ & $90,03 \%$ \\
\hline
\end{tabular}

The existence of this Islamic Social Entrepreneurship Learning Model is very strategic and important to improve potential human resources in the future. It is related to the study of (Boulven et al., 2018) that shows the Islamic Social Entrepreneurship model in human resource development. However, it can be used as a forum to develop a business, especially from the results of student craft into a product that is profitable and desirable in the market. In addition, this program also trains student's independence and understands how to be entrepreneurs in the Islamic concept. The activities in these learning are also able to increase the productivity of students to make handicrafts, which contribute to increasing the additional income and quality of life by students, especially in rural areas. This program also has an impact on the behavior change of high school students who originally possessed: (1) low interest in learning and (2) behavior to not care about their environment.

In general, the concept of entrepreneurship by the Islamic perspective has 4 aspects according to (Ramadani et al., 2016) shows in Figure 4 below.

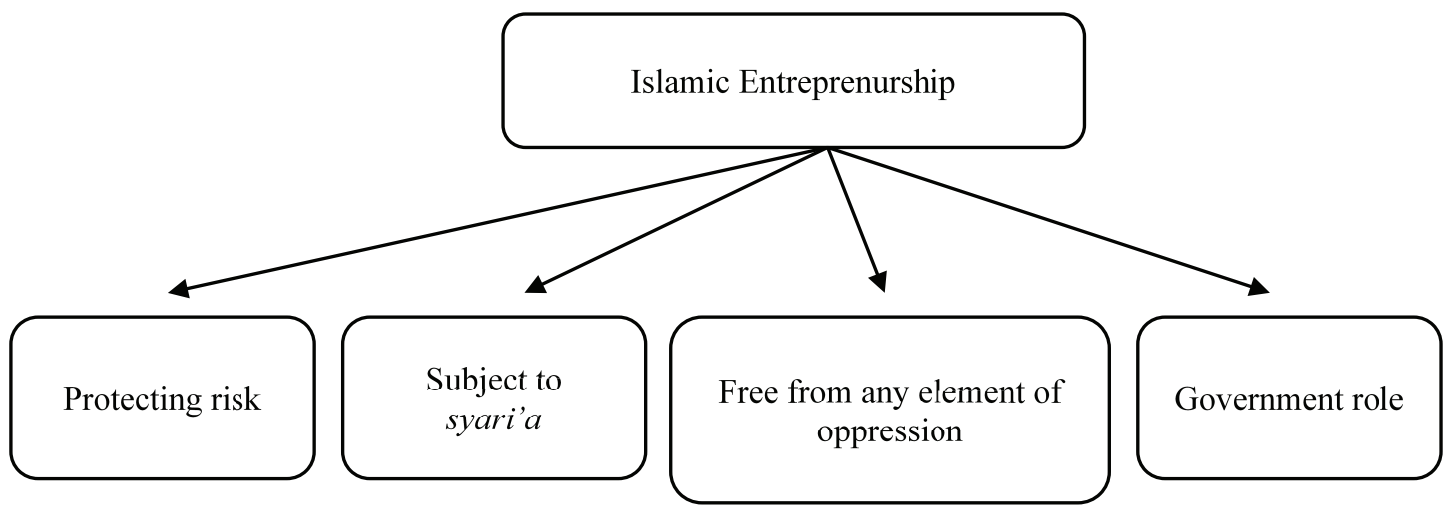

Figure 5: The concept of Islamic Entrepreneurship

Entrepreneurship in the Islamic perspective is closely considered some principle of thoughts. First is protecting risk, we know that entrepreneurship is close with the risky activity, in Islamic Economics an entrepreneur has protection from the risk by a law of Islamic as mean to decrease the risk and gain justice. Second is subject to shari'a, the difference between conventional economics and Islamic economics emphasizes how a 
Moslem generates, manages, and spends treasure. It can be seen from their behavior like avoiding riba, understanding halal, haram and syubhat, being honest and sincere to the society and customers. Third is free from any element of oppression, as a Moslem entrepreneur assigns a distinction between justice and freedom, and forbidden from being cruel or harm to society. Fourth is government role, government role also really important in doing business, not only conventional entrepreneurs, Islamic entrepreneurs should examine government role for their business. The Islamic Social Entrepreneurship Learning Model that was developed is suitable for that principle. In the learning model activity that was done by the high school student become one of the implementation from this principle.

The Islamic Social Entrepreneurship Learning Model that was developed also refers to the primary resource in Islamic Religion which is Al-Qur'an and Hadith or usually called Al-Falah. The concept of Islamic Social Entrepreneurship to achieve this concept includes three phases that are research about social entrepreneurship in general, research on social entrepreneurship based on model and concept, and the concept of social entrepreneurship based on Islamic perspective eg. Al-Qur'an and Hadith (Boulven et al., 2018). In this case, high school students not only understand how to be an entrepreneur, but also they will understand how to build up their business based on Islamic perspective.

Several Islamic concepts that were developed in this learning model will force the high school student to practice the high moral value. The Holy al-Qur'an and the traditions of the Prophet Muhammad SAW explicitly praise entrepreneurship and commend moral entrepreneurial activity such as the elimination of riba (P. R. M et al., 2013). This education is an initial form of assistance to high school students before later given assistance on growing innovative attitudes on themselves, skills, and knowledge in Islamic Social Entrepreneurship.

\section{Conclusion}

Based on the analysis above, we can conclude that Islamic Social Entrepreneurship examined as a new terminology in the reach of actual social entrepreneurship practice. The social entrepreneurship concept that accomplished by the Western view before can collaborate with the Islamic concept. After identifying the learning problem in entrepreneurship education such as first, students' lack of interest to learn and explore this subject, second, the teacher finds a difficult thing in teaching entrepreneurship subject, third, there are lots of students was complained that the learning media used 
by the teacher was not attractive and irrelevant to the current condition, Islamic Social Entrepreneurship Learning Model was developed as an alternative strategy success to increase teacher and student activity in entrepreneurship learning.

The learning activity that developed in this model not only examines profitable business but also examines how they have success life in the world and the hereafter. It can be achieved by giving understanding about the collaboration between entrepreneur and Islamic concept to the high school student. By the implementation of the Islamic Social Entrepreneurship Learning Model that was developed, we can see the change of economic behavior and lifestyle from high school students. This school model suitable for the real condition from the student and can implement sustainability to make entrepreneurship education success

Besides, this study can be an additional reading of material in the implementation of the Islamic Social Entrepreneur concept to overcome the learning problem in entrepreneurship. Furthermore, this study can be a pioneer of Micro Small and Medium Enterprises (MSMEs) existence in Indonesia to support growth in domestic product improvement. This study was recommended various parties to participate and take initiative to increase the implementation success of the Islamic Social Entrepreneurship model in their environment by examined more government policy that can not be reached by this study.

\section{Acknowledgement}

The author would like to thank the Ministry of Research Technology and Higher Education, Universitas Negeri Malang for supporting this study.

\section{References}

[1] Agbai, E. P. (2018). Scholar Works Pathways to Entrepreneurship Training Towards Addressing Youth Unemployment in Nigeria. Retrieved from https://scholarworks. waldenu.edu/dissertations. [01 January 2020]

[2] Al-Qur’an, A.-K. (2010. Surah Al-Baqarah [2:245] - Al-Qur'an al-Kareem - القرآن الكريم. Retrieved from https://quran.com/2/245.[01 January 2020]

[3] Almarri, J. (2015). A B C D E F G Scientiae Rerum Naturalium Humaniora Technica Medica Scientiae Rerum Socialium Scripta Academica Social Entrepreneurship in Practice.Inder Science. Qatar 
[4] Boulven, M. A., et al. (2018). Model of Islamic Social Entrepreneurship: A Study on Successful Muslim Social Entrepreneur in Malaysia. MATEC Web of Conferences, Vol. 150 (1), pp. 10-13.

[5] Cosenz, F. and Noto, G. (2017). Turning A Business Idea into a Real Business Through an Entrepreneurial Learning Approach Based on Dynamic Start-Up Business Model Simulators. Research Gate: Berlin

[6] Mulyaningsih, D. H. (2014). Initial Conceptual Model of Knowledge-Based Social Innovation. World Applied Sciences Journal, 30(30), pp. 256-262.

[7] Genefri, K. I., Dewy, M. S. and Anori, S. (2017). Learning Outcomes in Vocational Study: A Development of Product Based Learning Model. Medwell Journal, vol. 12, issue 5, pp. 831-838.

[8] Kurowska-Pysz, J. (2016). Opportunities for Cross-Border Entrepreneurship Development in a Cluster Model Exemplified by the Polish-Czech Border Region. Sustainability (Switzerland), vol. 8, issue 3. pp. 1-10

[9] Lin, R. F., Yan, H. D. and Wu, C. Y. (2018). Social Entrepreneurship and Charismatic Leadership: Master Cheng Yen and Tzu Chi Foundation. International Journal of Innovation and Regional Development, vol. 8, issue 2, p. 136.

[10] Nalyanya, C., Ndemo, B., \& Gathungu, J. (2015). The Significance of Faith Based Enterprises in the Dual Roles of Social Good and Economic Development in Kenya. DBA Africa Management Review, 5(2)..

[11] Faizal, P. R. M., Ridhwan, A. A. M., \& Kalsom, A. W. (2013). The Entrepreneurs Characteristic from al-Quran and al-Hadis. International Journal of Trade, Economics and Finance, vol. 4, issue 4.191

[12] Nawi, N. R. C., Arshad, M. M., Krauss, S. E., \& Arif, I. (2018). Social Entrepreneur as Career: Why it Attracts Youth in Malaysia?. Sciences, 8(6), 24-36.

[13] Ramadani, V., et al. (2016). Entrepreneurship and Management in an Islamic Context. Entrepreneurship and Management in an Islamic Context, September issue, pp. 1248.

[14] Ramoglou, S., \& Zyglidopoulos, S. C. (2015). The constructivist view of entrepreneurial opportunities: a critical analysis. Small Business Economics, 44(1), 71-78..

[15] Ramoglou, S. and Tsang, E. W. K. (2016). A Realist Perspective of Entrepreneurship: Opportunities as Propensities. Q Academy of Management Review, vol. 41, issue 3, pp. $410-434$.

[16] Short, J. C., Moss, T. W. and Lumpkin, G. T. (2009). Research in Social Entrepreneurship: Past Contributions and Future Opportunities. Strategic Entrepreneurship Journal Strat.,3(2), 161-194. 
[17] Teece, D. J. (2010). Business Models, Business Strategy and Innovation. Long Range Planning, 43(2-3), 172-194.

[18] Wirtz, B. W., Pistoia, A., Ullrich, S., \& Göttel, V. (2016). Business models: Origin, development and future research perspectives. Long range planning, 49(1), 36-54.

[19] Yulastri, A., et al. (2017). Developing an Entrepreneurship Module by Using Product-Based Learning Approach in Vocational Education. International Journal of Environmental and Science Education, vol. 12, issue 5, pp. 1097-1109.

[20] Zampetakis, L. A., et al. (2017). An Emotional Experience of Entrepreneurship: SelfConstrual, Emotion Regulation, and Expressions to Anticipatory Emotions. Journal of Career Development, vol. 44, issue 2, pp. 144-158. 